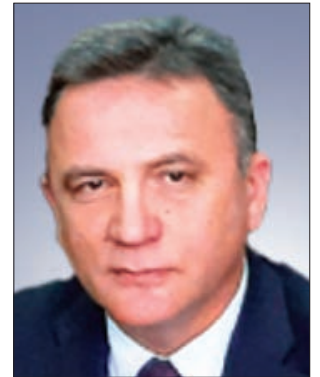

Hennadii V. Pavlov

Павлов

Геннадій

Вікторович

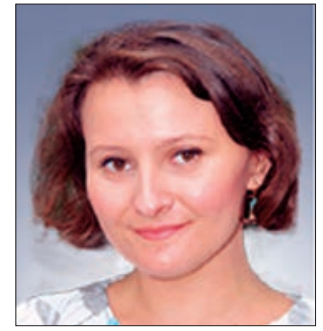

Iryna L.

Vinnychenko

Вінниченко

Ірина

Леонідівна

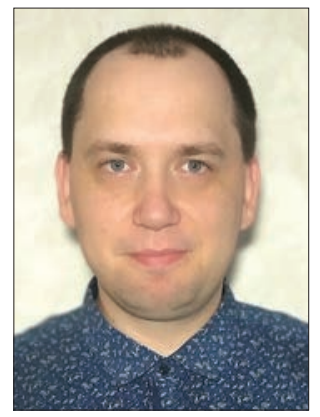

Dmytro V. Vinnychenko

Вінниченко

Дмитро

Валерійович

UDC 621.314

\title{
RESEARCH OF THE PROCESSES IN RESONANT FLYBACK CONVERTER FOR CONTACTLESS BATTERY CHARGING
}

\section{ДОСЛІДЖЕННЯ ПРОЦЕСІВ У РЕЗОНАНТНОМУ ОБЕРНЕНОХОДОВОМУ ПЕРЕТВОРЮВАЧІ ДЛЯ БЕЗКОНТАКТНОЇ ЗАРЯДКИ АКУМУЛЯТОРІВ}

DOI https://doi.org/10.15589/smi2021.1(15).3

Hennadii V. Pavlov ${ }^{1}$

Павлов Геннадій Вікторович, докт. техн. наук, проф. pavlov.gv.nuk@gmail.com ORCID: 0000-0002-4937-1828

Iryna L. Vinnychenko ${ }^{1}$ Вінниченко Ірина Леонідівна, канд. техн. наук i.l.vinnychenko@gmail.com ORCID: 0000-0002-3768-1060

Dmytro V. Vinnychenko² Вінниченко Дмитро Валерійович, канд. техн. наук vdvvvs@gmail.com ORCID: 0000-0002-8894-860X

\section{${ }^{1}$ Admiral Makarov National University of Shipbuilding, Mykolayiv Національний університет кораблебудування імені адмірала Макарова, м. Миколаїв}

${ }^{2}$ Institute of Pulse Processes and Technologies of National Academy of Sciences of Ukraine, Mykolaiv

Інститут імпульсних процесів і технологій Національної академії наук України, м. Миколаїв

Abstract. In the paper the circuit of the flyback converter for contactless battery charging is proposed and its operational principles are analyzed. The electromagnetic processes in the power circuit of the flyback converter are analyzed for contactless inductive energy transfer as well. The research aim of the paper is using the dissipation inductance of the resonant flyback transformer as a parameter of the resonant circuit to provide a given battery charging current and to obtain the corresponding analytical dependences needed for calculating the time sequences of the output current pulses and forming a given shape of the battery charging voltage curve. Using mathematical modeling and simulation, the processes in the power section of the converter were analyzed. The proposed converter allows combining the advantages of the flyback topology, switching the power transistor at zero current value due to the use of the resonance phenomenon, and significantly reducing the number of reactive elements due to the use of parasitic parameters of the transformer. Providing the proposed algorithm for switching the converter switches and ensuring the sequence of inter-switching stages described in the article will reduce the switching losses of the converter. During the analysis of electromagnetic processes in the converter, the analytical dependencies, which consider the parasitic and non-parasitic transformer parameters, the load parameters and the output and resonant characteristics of the converter, are obtained. 
The research results can be applied to the design of the highly efficient secondary power sources with high electromagnetic compatibility. The simulation results confirmed the adequacy of the relationships. Received analytical dependencies allow calculating the sequence of pauses' durations between the output current pulses in order to obtain a given shape of the charging voltage curve. They can be used in the future development of the control law in the case of pulse-position regulation.

Key words: flyback converter; contactless energy transfer; parasitic parameters of transformer; resonant circuit; electromagnetic processes.

Анотація. У статті запропоновано схему зворотного перетворювача для безконтактної зарядки акумуляторів, проаналізовано принципи ії роботи й електромагнітні процеси у силовій частині оберненоходового перетворювача для безконтактної індуктивної передачі електроенергії. Метою дослідження є використання індуктивності розсіювання трансформатора резонансного оберненоходового перетворювача як параметра резонансного ланцюга для забезпечення заданого струму зарядки акумулятора й отримання відповідних аналітичних залежностей, необхідних для розрахунку часових послідовностей імпульсів вихідного струму та формування заданої форми кривої напруги заряду акумулятора. За допомогою математичного й імітаційного моделювання були проаналізовані процеси у силовій частині перетворювача. Представлений перетворювач дозволяє поєднати переваги оберненоходової топології, переключення силового транзистора при нульовому значенні струму завдяки використанню задіяного явища резонансу і значно зменшує кількість реактивних елементів завдяки використанню паразитних параметрів трансформатора. Застосування описаного алгоритму перемикання ключових елементів схеми та забезпечення послідовності міжкомутаційних етапів, описаної у статті, дозволить знизити комутаційні втрати перетворювача. Під час аналізу електромагнітних процесів у перетворювачі отримано аналітичні залежності, що поєднують паразитні та непаразитні параметри трансформатора, параметри навантаження та вихідні та резонансні характеристики перетворювача. Результати досліджень можуть бути застосовані для проектування високоефективних вторинних джерел живлення з високою електромагнітною сумісністю. Результати моделювання підтвердили адекватність отриманих аналітичних залежностей. Отримані аналітичні залежності дозволяють розрахувати послідовність без імпульсних проміжків вихідного струму, щоб отримати задану форму кривої зарядної напруги. Вони можуть бути використані для подальшої розробки закону управління у разі застосування фазо-імпульсного регулювання.

Ключові слова: оберненоходовий перетворювач; безконтактна передача енергії; паразитні параметри трансформатора; резонансний контур; електромагнітні процеси.

\section{References}

[1] Pressman, A., Billing, K., Morey T. (2009). Switching power supply design, 3rd ed. The McGraw-Hill Companies, $880 \mathrm{p}$.

[2] Bose, B. (2002). Modern power electronics and AC drives. Prentice-Hall Inc., 738 p.

[3] Montes, O. A., Son, S., Kim, S., Seok, H., Lee, J. S., Kim M. (2017). Forward-flyback resonant converter for high-efficient medium-power photovoltaic applications. IEEE Applied power electronics conference and exposition (APEC), pp. 1223-1228. Doi: 10.1109/APEC.2017.7930851

[4] Xu, S., Shen, W., Qian, Q., Zhu, J., Sun W., Li, H. (2019). An efficiency optimization method for a high frequency quasi-ZVS controlled resonant flyback converter. IEEE Applied power electronics conference and exposition (APEC), pp. 2957-2961. Doi: 10.1109/APEC.2019.8722026

[5] Pavlov, G., Vinnichenko, I., Pokrovskiy, M. (2018). Estimation of energy efficiency of the frequency converter based on the resonant inverter with pulse-density control. Proc. of IEEE 3rd international conference on intelligent energy and power systems (IEPS), pp. 101-105. Doi: 10.1109/IEPS.2018.8559499

[6] Moradewicz, A. Contactless energy transmission system with rotatable transformer - modeling, analyze and design (PhD Thesis) (2008). Poland, Warsaw: Electrotechnical Institute, $118 \mathrm{p}$

[7] Matias, R., Dinis, J., Fonseca, J.A., Ferreira, J., Pedreiras, P. (2015). Energy issues of bike sharing systems: From energy harvesting to contactless battery charging. IEEE 24th international symposium on industrial electronics (ISIE), pp. 288-293. Doi: 10.1109/ISIE.2015.7281483 
[8] Li, T., Wang, X., Zheng, Sh., Liu, Ch. (2018). An efficient topology for wireless power transfer over a wide range of loading conditions. Energies, 11 (141), pp. 1-16. Doi:10.3390/en11010141

[9] Wu, S., Chang, Yo., Chang, Ch., Cheng, Y. (2019). A fast charging balancing circuit for LiFePO4 battery. Electronics, 8, pp. 1144-1159. Doi:10.3390/electronics8101144

[10] Chen, M., Rincon-Mora, G. A. (2007). Accurate electrical battery model capable of predicting runtime and I-V performance. IEEE Transactions on Energy Conversion, 21 (2), pp. 504-511. Doi: 10.1109/TEC.2006.874229

Problem statement. The growth in the number of autonomous electricity consumers, both for customer and industrial purposes, requiring a portable power source, leads to the need to improve existing devices for their charge. This problem may be relevant for the refrigerated vessels, the carrying capacity of which reaches 8-12 thousand tons. To carry out such volume of the loading work, a correspondingly significant number of mobile electric loading mechanisms are required. Their batteries possibly parallel charging process may cause an urgent problem of the creation of the energy-efficient chargers that will have the minimal affect on the quality of electricity in the power network. This article discusses a flyback power converter, which can be successfully applied both in the process of contactless charging of the small reserve capacity batteries, and the batteries used as the power supply for the on-board networks of medium power.

Latest research and publication analysis. Designing the charger, including wireless ones, the developer bases on its ability to provide a given form of charging voltage curve and effectively control this form. The most popular nowadays from the point of view of control are the pulse control methods [1, p. 162; 2, p. 210], which are also used in flyback converters widely applied in various industrial applications [3, p. 1224; 4, p. 2957]. The use of resonant and quasi-resonant circuits with transistors commutation at zero values of current and voltage in combination with pulse regulation allows to fully use the advantages of each of the approaches, including improving the efficiency of the converter, reducing the overall dimensions of the device and ensuring the electromagnetic compatibility of the charger with the network [5, p. 101].

It should also be noted that non-contact methods of power transmission are often used to charge batteries, based on the use of alternating electric (capacitive coupling) and magnetic (inductive coupling) fields, which allow avoiding such a significant drawback as the failure of contact connectors as a result of their frequent use. Inductive coupling is achieved through the use of transformers with a large air gap, the configuration of the magnetic circuit of which depends on the purpose of the system [6, p. 5]. In capacitive coupling, the air gap between the plates of the capacitor plays the role of a dielectric [6, p. 5]. Since the area of the capacitor plates for a capacitive wireless energy transfer should increase in proportion to the device power, and to transfer energy through the large gap, it is necessary to apply a large potential difference to the plates, capacitive connections are most widespread in devices with a power of up to tens of $\mathrm{mW}[6, \mathrm{p} .6]$. Inductive connections turned out to be more versatile, and are used in systems with a power from a few $\mathrm{mW}$ to hundreds of $\mathrm{kW}[6, \mathrm{p} .6]$.

Thus, let us consider in more detail the contactless inductive principle of energy transfer. For wireless converters based on the inductive energy transfer, the transformer's primary and secondary windings of which belong to different devices, the main factor affecting the charging characteristics is widely varying dissipation inductance [7, p. 289]. The successful use of parasitic parameters of the transformer used for inductive power transmission in a bridge converter is demonstrated in [8, p. 1]. The flyback topology assumes the presence of one transistor instead of 4, comparing the bridge topology, which greatly simplifies the design of the control system. The use of a resonant flyback converter for power transmission, using the parasitic parameters of the transformer in its operation, is not canonical and will allow excluding external resonant reactive elements 
from the circuit. Therefore, this approach requires additional study.

To simulate the battery charging process, people may use the electrical battery model proposed in $[10$, p. 506]. In this model, the battery's charging ability is simulated by the capacitor charging circuit with the current-controlled current source. The control current is determined from the model of the particular capacitor depending on its state of charge [10, p. 505]. However, in that paper, the model of an ideal current source is used. In the current paper the main task is to propose the real close to ideal current source, to describe it analytically, to obtain the analytical solutions for the characteristics of the charging process and to verify them using the software simulation.

The article aim. Thus, the research aim of the paper is using the dissipation inductance of the resonant flyback transformer as a parameter of the resonant circuit to provide a given battery charging current and to obtain the corresponding analytical dependences needed for calculating the time sequences of the output current pulses and forming a given shape of the battery charging voltage curve.

Methods, object and subject of study. The method of mathematical modeling was used to solve the problem. The object of research is electromagnetic processes in resonant flyback converters of electricity, which use the parasitic parameters of the transformer as the elements of the resonant circuit. The subject of research is the resonant inverters for contactless inductive energy transfer.

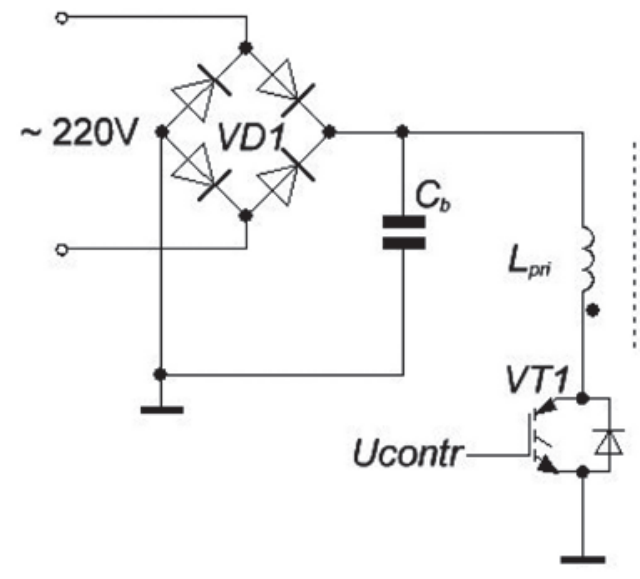

The basic material (results). Figure 1 shows the power circuit of the resonant flyback converter for contactless battery charging.

The AC input voltage, rectified with the diode bridge $V D 1$, and filtered with the capacitor $C_{b}$. The air gap transformer, formed with the magnetically coupled inductors $L_{p r i}$ and $L_{s e c}$ allows apportioning the stationary and mobile parts of the converter. The resonance occurs between the transformers own parameters, which include both leakage inductance $L_{s}$ and parasitic capacitance of the transformer windings $C_{r 1}$ and the additional resonant capacitor $C_{r 2}$. The battery is conventionally depicted as the capacitor $C_{\text {out }}$. The diode $D$ allows sharing out the forward and reverse direction of the energy transfer within the circuit. The battery's voltage $U_{\text {out }}$ one should control because of the specific features of the battery charging process, especially due to the requirement for a process of so-called fast charging, which should stop at $70 \%$ of the rated output voltage of the battery [9, p. 13].

Using the equivalent circuit of the transformer, one can present the converter in the form of the circuit in fig. 2.

The combination of chokes $L_{s 1}$ and $L_{s 2}$ present here the leakage inductance $L_{s}$ (fig. 3) of the transformer. The parasitic resistance of the transformer windings is represented by the resistors $R_{s 1}$ and $R_{s 2}$. The parasitic capacitance of the transformer $C_{r 1}$ together with the additional capacitor $C_{r 2}$ forms the resonant capacitance $C_{r}$.

To analyze the electro-magnetic processes in the circuit, one may divide the conversional

Fig. 1.

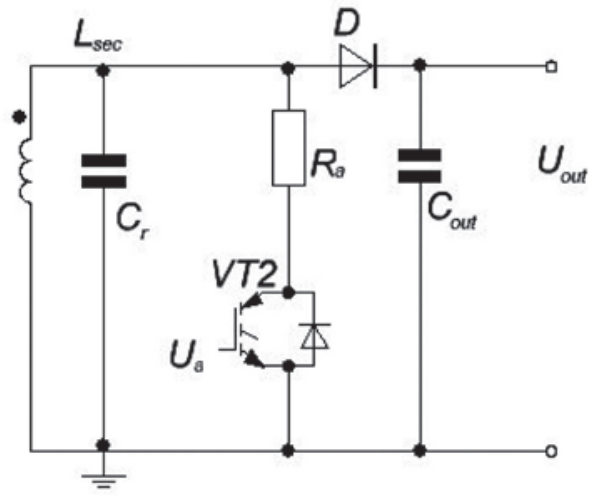


phase into 6 stages, the equivalent circuits of the converter during which are shown in fig. 3 .

The proposed topology of the resonant flyback converter for contactless battery charging causes the presence of 2 resonant circuits that affect the charging of the battery: the first resonant circuit $R C 1$ is formed with the leachage inductance of the transformer $L_{s}$

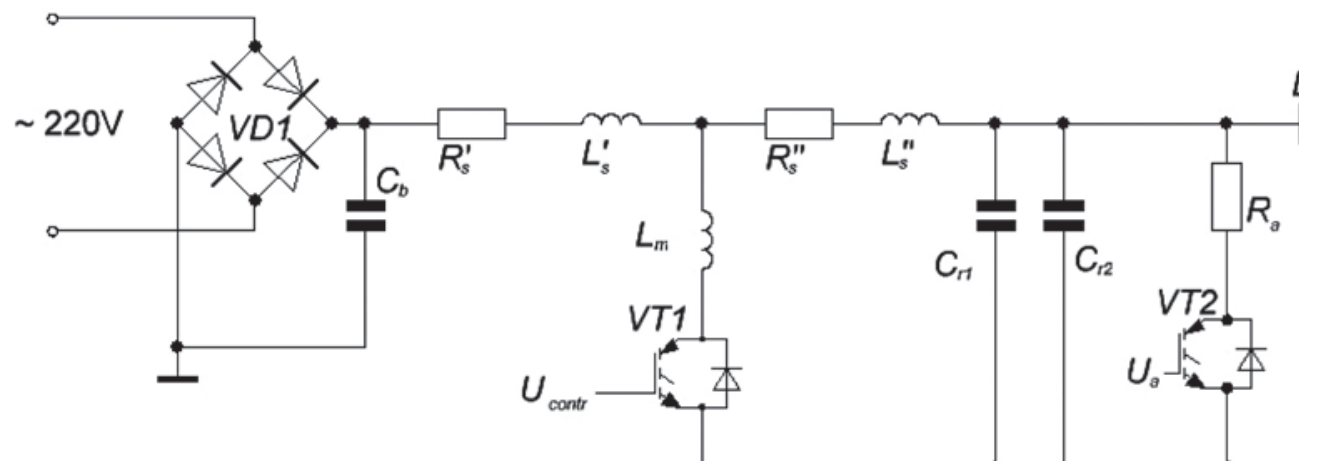

Fig. 2.
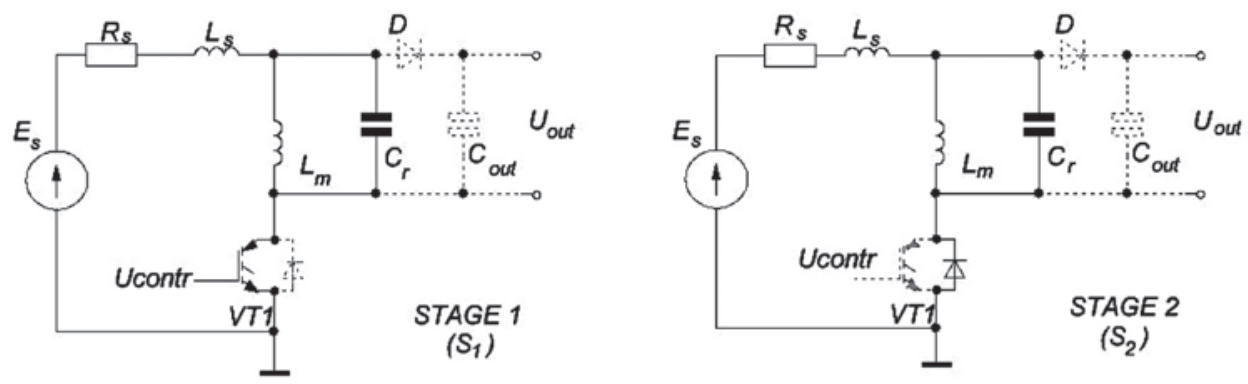

$a$
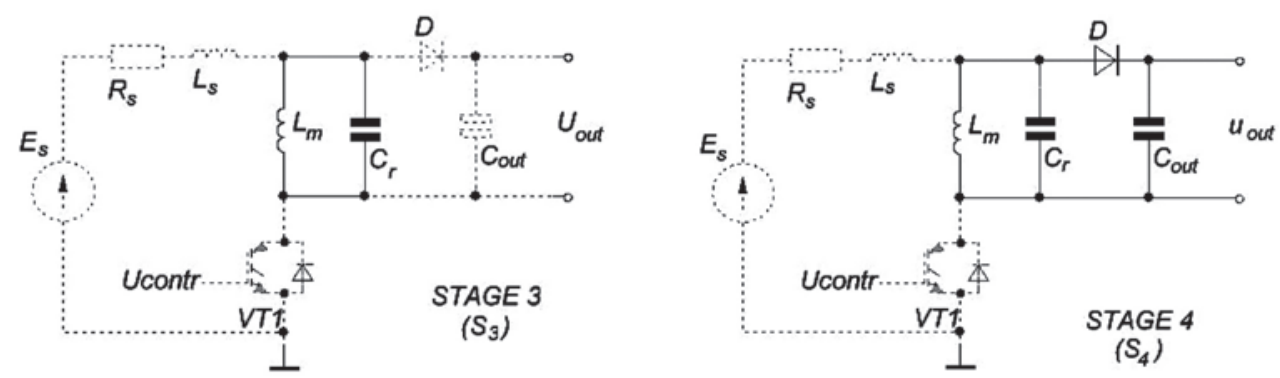

$c$
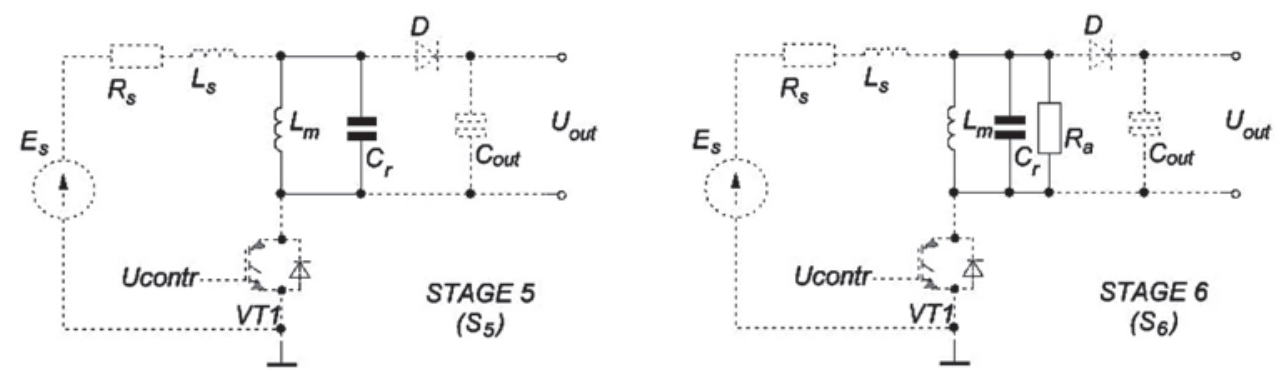

Fig. 3. 
and the resonant capacitor $C_{r}$. Donate the period of the natural oscillations of the curren resonant circuit as $T_{r s}=2 \pi \sqrt{L_{s} C_{r}}$ (fig. 4). The second resonant circuit $R C 2$ consists of the magnetization inductance $L_{m}$ and the resonant capacitor $C_{r}$. Donate the period of the natural oscillations of the current resonant circuit as $T_{r m}$ (fig. 4). During the following analysis consider that the parasitic resistance $R_{s}$ of the transformer is extremely small. The quasi-resonance mode of the first circuit one can observe in 1 st and 2 nd stages (fig. 3, a-b), and the second circuit - in the 3rd stage (fig. 3, c). During the 1st and 2nd stages the magnetic energy is pumped into the magnetization inductance $L_{m}$, so the inductance $L_{m}$ is charged up to the current value

$$
I_{L m}=\frac{1}{L_{m}} \int_{0}^{t_{2}} u_{C r} d t
$$

According to [10], the average value of the voltage pulse $u_{C r}$ with the form, shown in fig. 4 is as follows:

$$
\begin{gathered}
\int_{0}^{t_{2}} u_{C r} d t=E_{s} T_{r s}, \text { thus, } \\
I_{L m}=\frac{E_{s} T_{r s}}{L_{m}}
\end{gathered}
$$

During the third stage (fig. 3c), the resonant capacitor $C_{r}$ is charged with the energy stored in $L_{m}$. Denote the voltage on the resonant capacitor at the beginning of this step by $u_{C r b}$ and at the end of step $u_{C r}$.

The average charging current of the resonant capacitor during this stage $T_{c h r}=t_{3}-t_{2}$ :

$$
i_{C r_{-} a v}=\frac{1}{T_{c h \_r}} \int_{0}^{T_{c h r} r} i_{L m} d t=\frac{C_{r}\left(u_{C r_{-} e}-u_{C r_{-} b}\right)}{T_{c h \_r}} .
$$

Equation (2) relates two unknown quantities needed for further calculation: the duration of the resonant capacitor charging $T_{c h r}$ and the voltage of the resonant capacitor at the end of the charging stage $u_{C r} e$.

At the end of the resonant capacitor charging, its voltage $u_{C r}$ is equal to the sum of the voltage at the output capacitor $u_{\text {Cout }}$ and the forward voltage drop of the diode $\mathrm{D}$ :

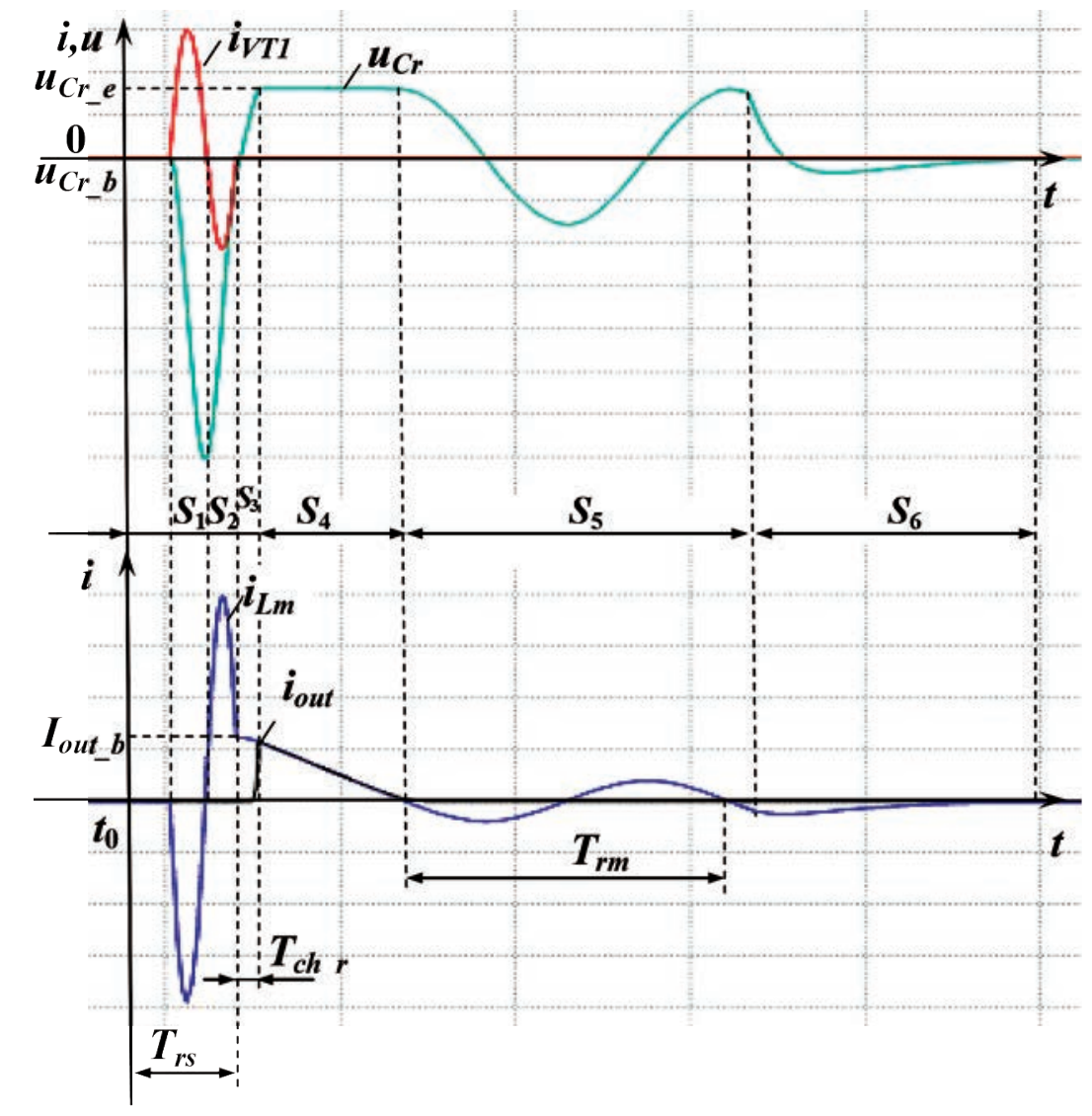

Fig. 4. 


$$
u_{\text {Cr_e }}=u_{\text {Cout }}+u_{D} .
$$

Knowing $u_{\text {Cout }}$ one can find the charging time of the resonant capacitor $T_{c h_{-}}$using (2).

During the capacitor $C_{r}$ charging, the current of the resonant circuit changes according to the close to cosine law.

$$
i_{L m}=I_{L m} \cos \left(\omega_{r m} t\right),
$$

where $\omega_{r m}=2 \neq / T_{r m}$ - cyclic natural frequency of the resonant circuit; $I_{L m}$ - the resonant circuit current amplitude.

Substitute (4) under the sign of the equation (2) left side integral and obtain

$$
\begin{gathered}
\frac{1}{T_{c h \_r}} \int_{0}^{T_{c h r} r} I_{L m} \cos \left(\omega_{r m} t\right) d t= \\
=\frac{1}{T_{c h \_r}} I_{L m} \frac{\sin \left(\omega_{r m} T_{c h \_r}\right)}{\omega_{r m}} .
\end{gathered}
$$

Equate the expression obtained in (5) to the right side of equation (2), reducing $T_{c h_{r}}$ :

$$
C_{r}\left(u_{C r_{-} e}-u_{C r_{-} b}\right)=I_{L m} \frac{\sin \left(\omega_{r m} T_{c h_{-} r}\right)}{\omega_{r m}} .
$$

We get the duration of resonant capacitor $C_{r}$ charging in the third stage:

$$
T_{\text {ch_r } r}=\frac{\arcsin \left(\frac{C_{r} u_{C_{-} e} \omega_{r m}}{I_{L m}}\right)}{\omega_{r m}} .
$$

During the next stage (fig. 3d), the battery, represented in the diagram by the capacitor $C_{\text {out }}$ is charged.

The initial charging current $I_{\text {out } b}$ can be found from the equation (4), substituting the time from (7):

$$
I_{\text {out } \_b}=I_{L m} \cos \left(\omega_{r m} T_{c h \_r}\right) .
$$

All the energy stored in $L_{m}$ during this stage converts into the energy of the capacitors $C_{\text {out }}$ and $C_{r}$, and is distributed proportionally to their capacities.

$$
\frac{L_{m} \cdot I_{\text {out } \_b}^{2}}{2}=\frac{\left(C_{\text {out }}+C_{r}\right)\left(u_{\text {out } e}^{2}-u_{\text {out } \_b}^{2}\right)}{2},
$$

where $u_{\text {out }_{e}}$ is the voltage at the output capacitor at the end of the charging process, $u_{\text {out } b}$ is the output capacitor voltage at the beginning of charging.

We divide (9) by (6) term by term taking into account (1):

$$
\frac{\cos ^{2}\left(\omega_{r m} T_{c h \_r}\right)}{\sin \left(\omega_{r m} T_{\text {ch_r } r}\right)}=A \cdot \frac{u_{\text {out_e }}^{2}-u_{\text {out } \_b}^{2}}{u_{\text {out_e }}},
$$

where $A=\frac{C_{\text {out }}}{C_{r}} \frac{1}{E_{s} T_{\text {ch_r }}} \frac{1}{\omega_{r m}}$.

The output capacitor voltage $u_{\text {out } e}$ at the end of its charging can be calculated by knowing the voltage $u_{\text {out } \_b}$ at the beginning of the charging process.

During the $5^{\text {th }}$ stage (fig. 3, e), right after decreasing the output current to 0 and closing the diode $D$, the resonant oscillations in the resonant tank $L_{m}-C_{r}$ occur with the natural frequency of $f_{r m}=1 / T_{r m}$ (fig. 4). To reduce the initial conditions to zero for the next cycle, during the $6^{\text {th }}$ stage (fig. $3, f$ ) the resonant circuit is shunted with the resistor $R_{a}$.

Discussion of the results. To simulate the operation of the flyback converter for contactless battery charging and verify the analytical dependences, which describe the electromagnetic processes in the power circuit of the converter, the simulation is implemented in LTspice. The simulation model of the converter is shown in fig. 5, a. The charging current $i_{\text {out }}$ of the battery (fig. 5, b), which is presented in the model with the capacitor $\mathrm{C} 3=200 \mathrm{uF}$, is a triangularshaped high-frequency pulse one, according to the preconditions for development of analytical dependences describing electromagnetic processes shown in fig. 4.

Fig. 5, c shows the form of the battery charging voltage with the constant time intervals between the control pulses, supplied to the transistor $V T 1$ (fig. 1), represented in the model by the ideal switch $S 1$ with diodes $D 2-D 3$ and resistor $R 4$.

Comparison of the battery charging voltage curve $u_{\text {out } c}$, calculated according to the dependences (1) - (10), and the curve $u_{\text {out } s}$ obtained in the simulation results shows their practical coincidence (Fig. 6).

Thus, one may use the obtained equations (1) - (10) during the calculation of the sequence of pauses' durations between the output current pulses to obtain a given shape of the charging voltage curve.

Conclusion. In the paper, the flyback converter for contactless battery charging is pro- 


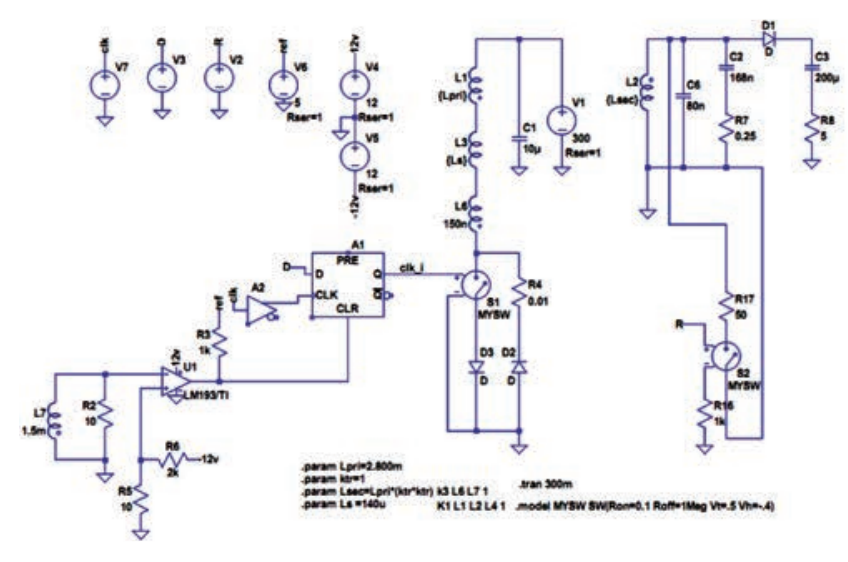

a

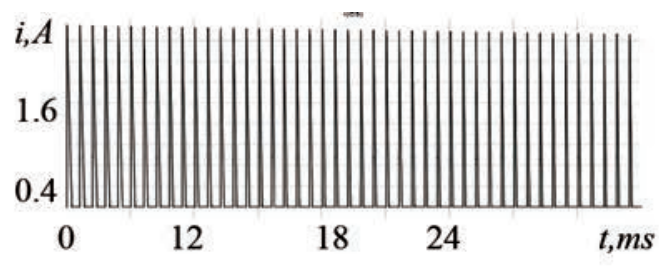

b

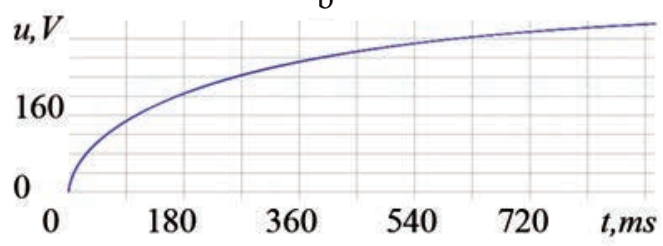

c

Fig. 5.

posed, in which the resonant circuit is formed by the dissipation inductance of the transformer and the additional resonant capacitor. The operation of the converter during one operating cycle, which includes the time interval between the beginnings of two subsequent control pulses, is analyzed. The switching of the power transistor occurs at zero current values. During the analysis of electromagnetic processes in the converter, the analytical dependencies have been obtained, which relate the parameters and characteristics of the converter and the charging process time. They allow calculating the sequence of pauses' durations between the output current pulses in order to obtain a given shape of the charging

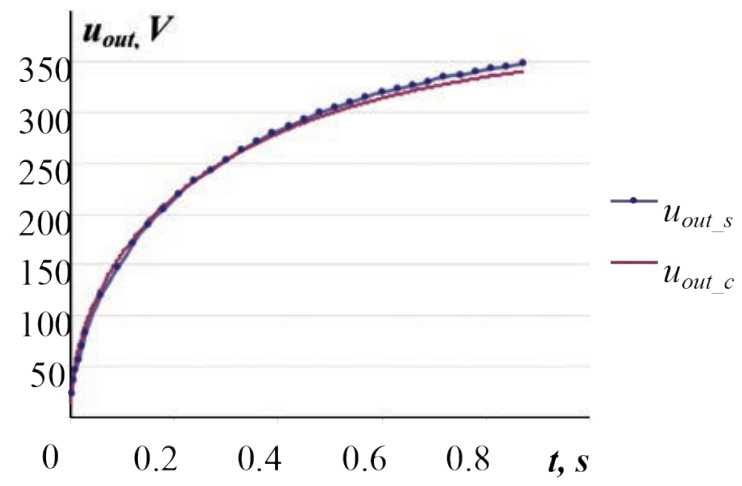

Fig. 6.

voltage curve. They can be used in the future development of the control law in the case of pulse-position regulation.

\section{List of literature}

[1] Pressman, A., Billing, K., Morey T. Switching power supply design. The McGraw-Hill Companies, 2009. $880 \mathrm{p}$.

[2] Bose, B. Modern power electronics and AC drives. Prentice-Hall Inc., 2002. 738 p.

[3] Montes, O.A., Son, S., Kim, S., Seok, H., Lee, J.S., Kim M. Forward-flyback resonant converter for high-efficient medium-power photovoltaic applications. IEEE Applied power electronics conference and exposition (APEC). 2017. pp. 1223-1228. Doi: 10.1109/APEC.2017.7930851

[4] Xu, S., Shen, W., Qian, Q., Zhu, J., Sun W., Li, H. An efficiency optimization method for a high frequency quasi-ZVS controlled resonant flyback converter. IEEE Applied power electronics conference and exposition (APEC). 2019. pp. 2957-2961. Doi: 10.1109/APEC.2019.8722026

[5] Pavlov, G., Vinnichenko, I., Pokrovskiy, M. Estimation of energy efficiency of the frequency converter based on the resonant inverter with pulse-density control. Proc. of IEEE 3rd international conference on intelligent energy and power systems (IEPS). 2018. pp. 101-105. Doi: 10.1109/IEPS.2018.8559499

[6] Moradewicz, A. Contactless energy transmission system with rotatable transformer - modeling, analyze and design (PhD Thesis). Poland, Warsaw : Electrotechnical Institute, 2008. 118 p.

[7] Matias, R., Dinis, J., Fonseca, J.A., Ferreira, J., Pedreiras, P. Energy issues of bike sharing systems: From energy harvesting to contactless battery charging. IEEE 24th international symposium on industrial electronics (ISIE). 2015. pp. 288-293. Doi: 10.1109/ISIE.2015.7281483 
[8] Li, T., Wang, X., Zheng, Sh., Liu, Ch. An efficient topology for wireless power transfer over a wide range of loading conditions. Energies. 2018. № 11 (141). P. 1-16. Doi:10.3390/en11010141

[9] Wu, S. Chang, Yo., Chang, Ch., Cheng, Y. A fast charging balancing circuit for LiFePO4 battery. Electronics. 2019. № 8. P. 1144-1159. Doi:10.3390/electronics8101144.

[10] Chen, M., Rincon-Mora, G.A. Accurate electrical battery model capable of predicting runtime and I-V performance. IEEE Transactions on Energy Conversion. 2007. № 21 (2). P. 504-511. Doi: 10.1109/TEC.2006.874229.

(C) Павлов Г. В., Вінниченко І. Л., Вінниченко Д. В. Дата надходження статті до редакції: 06.04.2021 Дата затвердження статті до друку: 17.05.2021 